\title{
1 Mineralization of pentachlorophenol by \\ 2 ferrioxalate-assisted solar photo-Fenton process at 3 mild pH
}

4 Zhihong Ye $\mathrm{e}^{\mathrm{a}, \mathrm{b}}$, Ignasi Sirés ${ }^{\mathrm{b}}$, Hui Zhang ${ }^{\mathrm{a}, *}$, Yao-Hui Huang ${ }^{\mathrm{c}, *}$

$5 \quad{ }^{a}$ Department of Environmental Science and Engineering, Wuhan University, Wuhan

6 430079, China

7 baboratori d'Electroquímica dels Materials i del Medi Ambient, Departament de

8 Química Física, Facultat de Química, Universitat de Barcelona, Martí i Franquès

9 1-11, 08028 Barcelona, Spain

10 'Department of Chemical Engineering, National Cheng Kung University, Tainan 701,

11 Taiwan

12 * Corresponding author: E-mail address: eeng@whu.edu.cn. (H. Zhang) 


\section{Abstract}

This work reports the use of ferrioxalate complexes to assist solar photo-Fenton treatment of pentachlorophenol (PCP) in aqueous medium at mild $\mathrm{pH}$, which inhibits the precipitation of iron hydroxides and allows working at a low iron dosage. The experimental parameters were optimized by assessing the effect of initial concentrations of $\mathrm{H}_{2} \mathrm{O}_{2}(0-2.5 \mathrm{mM})$ and $\mathrm{Fe}(\mathrm{II})(2-10 \mathrm{mg} / \mathrm{L}), \mathrm{pH}(3.0-9.0)$ and iron/oxalic acid molar ratios (1:0-1:13.5) on total organic carbon (TOC) removal. Ferrioxalate-assisted solar photo-Fenton achieved 97.5\% mineralization in $120 \mathrm{~min}$, clearly outperforming conventional Fenton and solar photo-Fenton. The presence of photosensitive ferrioxalate complexes accounted for the enhancement, as a result of $\mathrm{Fe}(\mathrm{II})$ regeneration that accelerated the hydroxyl radical ( $\left.{ }^{\circ} \mathrm{OH}\right)$ production. The time course of $\mathrm{H}_{2} \mathrm{O}_{2}$ and $\mathrm{Fe}(\mathrm{II})$ concentrations was evaluated under different iron/oxalic acid ratios. The five carboxylic acids determined by ion-exclusion HPLC and the eight aromatic by-products identified by GC-MS allowed the proposal of a degradation pathway that included hydroxylation, dechlorination and dimerization steps. Complete chloride ion release was achieved after 90 min of treatment.

Keywords: Ferrioxalate complexes; Mild pH; Mineralization; Pentachlorophenol; Solar photo-Fenton 


\section{Introduction}

Chlorophenols, listed as priority pollutants by most water directives worldwide due to their high toxicity, are still massively employed in industrial and agricultural activities (Hechmi et al., 2016; Khuzwayo and Chirwa, 2017). Pentachlorophenol (PCP, $\mathrm{C}_{6} \mathrm{HCl}_{5} \mathrm{O}$ ), the highest chlorinated phenol, is widely used as herbicide, fungicide, insecticide and disinfectant, showing main applications in agriculture, wood preservation and industry (Amendola et al., 2017; Tsoufis et al., 2017). Although large-scale manufacture and application of PCP have been banned in Taiwan and mainland China since 1984 and 1997, respectively, its presence in water and soil has been regularly reported in the last three decades (Shih et al., 2016). Due to its long-term persistence, high toxicity and carcinogenicity, wastewater contaminated with PCP must be conveniently treated before being discharged or reused (Cui et al., 2017).

The solubility of PCP, with $\mathrm{p} K_{\mathrm{a}}=4.75$ (He et al., 2015; Guemiza et al., 2017), is highly dependent on $\mathrm{pH}$, being low at $\mathrm{pH}<5.0(\leq 14 \mathrm{mg} / \mathrm{L})$ but very high at $\mathrm{pH}>6.0$ (> $100 \mathrm{mg} / \mathrm{L}$ ) since its anionic form is predominant. As a result, it has been detected in industrial wastewater of $\mathrm{pH} 9.0$ at a concentration of $490 \mathrm{mg} / \mathrm{L}$ (Rahmani et al., 2018). Various technologies have been developed for the treatment of PCP in water, including biodegradation (Khan et al., 2017), adsorption (Zhou et al., 2014), chemical oxidation and reduction (Shih et al., 2016), electrochemical oxidation (Niu et al., 2013) and photocatalysis (Khuzwayo and Chirwa, 2017). Unfortunately, most of these methods exhibit several weaknesses like long treatment times required, high energy 
consumption, insufficient ability to ensure total removal and inefficient mineralization that causes the accumulation of toxic intermediates.

Nowadays, advanced oxidation processes (AOPs), including those based on Fenton's reaction, ozone and light irradiation, have been proven excellent to degrade highly recalcitrant organic compounds because of the action of hydroxyl radical ( $\mathrm{OH}$ ), which is the second strongest oxidant after fluorine with a high standard redox potential ( $E=2.80 \mathrm{~V} \mid \mathrm{SHE}$ ) (Martínez-Huitle et al., 2015). Among AOPs, Fenton’s reaction is recognized as a very simple way to generate ${ }^{\circ} \mathrm{OH}$. However, inefficient $\mathrm{Fe}(\mathrm{II})$ regeneration usually results in the need of large amounts of such catalyst, which must be carefully managed upon treatment completion (Brillas et al., 2009). The addition of UV irradiation gives rise to photo-Fenton process, which can readily regenerate $\mathrm{Fe}(\mathrm{II})$ and produce additional ${ }^{\circ} \mathrm{OH}$ amounts (Eq. (1)), as well as photodecarboxylate the $\mathrm{Fe}(\mathrm{III})$ complexes generated during the oxidation of most organics (Eq. (2)) (Ye et al., 2016).

$[\mathrm{Fe}(\mathrm{OH})]^{2+}+h \mathrm{v} \rightarrow \mathrm{Fe}^{2+}+{ }^{\bullet} \mathrm{OH}$

$[\mathrm{Fe}(\mathrm{OOCR})]^{2+}+h \mathrm{v} \rightarrow \mathrm{Fe}^{2+}+\mathrm{CO}_{2}+\mathrm{R}^{\bullet}$

Nonetheless, conventional Fenton process with simple soluble salts presents two critical limitations: (i) it demands acidic conditions ( $\mathrm{pH}$ 2.5-3.5) to maintain a high performance, which restricts the application of photo-Fenton process for wastewater treatment at large scale; and (ii) reaction (1) exhibits a quite low quantum yield for Fe(III) photoreduction $(\Phi(\mathrm{Fe}(\mathrm{II}))=0.14 \pm 0.04$ at $313 \mathrm{~nm})$, and might also be 
inhibited by the reduced light penetration when treating colored solutions (Pignatello et al., 2006).

To overcome these disadvantages, some chelating agents such as oxalate, citrate, ethylenediamine-N,N'-disuccinic acid (EDDS), ethylenediaminetetraacetic acid (EDTA) and nitrilotriacetic acid (NTA) have been investigated to upgrade the conventional photo-Fenton process (Klamerth et al., 2012; Manenti et al., 2015; Clarizia et al., 2017). Such compounds are able to form stable complexes with ferric ions, thereby maintaining the iron soluble at less acidic $\mathrm{pH}$ and acting as photoactive species that greatly enhance the performance of photo-Fenton process. Among these agents, oxalate has been shown to be preferred (Kwan and Chu, 2007). The advantages of ferrioxalate-assisted photo-Fenton as compared to other systems include (Luca et al., 2014; Souza et al., 2014; Clarizia et al., 2017): (i) the soluble ferrioxalate complex allows working at neutral $\mathrm{pH}$ values; (ii) this complex has a higher quantum yield for Fe(II) regeneration (Eqs. $(3,4)$ ); (iii) it exhibits more intense light absorption, with a range up to $580 \mathrm{~nm}$; and (iv) additional $\mathrm{H}_{2} \mathrm{O}_{2}$ production can occur from participation of dissolved oxygen (Eqs. (5-8)). The reaction network was summarized as follows (Souza et al., 2014; Clarizia et al., 2017):

$$
\left[\mathrm{Fe}\left(\mathrm{C}_{2} \mathrm{O}_{4}\right)_{\mathrm{n}}\right]^{3-2 \mathrm{n}}+h \mathrm{v} \rightarrow \mathrm{Fe}^{2+}+(\mathrm{n}-1) \mathrm{C}_{2} \mathrm{O}_{4}{ }^{2-}+\mathrm{C}_{2} \mathrm{O}_{4}{ }^{\cdot-}
$$

$\mathrm{C}_{2} \mathrm{O}_{4}{ }^{\cdot-}+\left[\mathrm{Fe}\left(\mathrm{C}_{2} \mathrm{O}_{4}\right)_{\mathrm{n}}\right]^{3-2 \mathrm{n}} \rightarrow \mathrm{Fe}^{2+}+\mathrm{nC}_{2} \mathrm{O}_{4}{ }^{2-}+2 \mathrm{CO}_{2}$

$\mathrm{C}_{2} \mathrm{O}_{4}{ }^{\cdot-}+\mathrm{O}_{2} \rightarrow \mathrm{O}_{2}^{\cdot-}+2 \mathrm{CO}_{2}$

$\mathrm{Fe}^{2+}+\mathrm{O}_{2} \rightarrow \mathrm{Fe}^{3+}+\mathrm{O}_{2}^{\cdot-}$

$$
\mathrm{O}_{2}{ }^{--}+\mathrm{H}^{+} \leftrightarrow \mathrm{HO}_{2} \cdot \quad \mathrm{p} K_{\mathrm{a}}=4.8
$$


$2 \mathrm{HO}_{2} \cdot \rightarrow \mathrm{H}_{2} \mathrm{O}_{2}+\mathrm{O}_{2}$

Considering the high energy consumption using artificial UV light sources, sunlight can be alternatively employed to operate the ferrioxalate-assisted solar photo-Fenton process, which has been proven to be an efficient wastewater treatment technology (Monteagudo et al., 2010; Souza et al., 2014; Expósito et al., 2018). The present work investigates the mineralization and dechlorination of PCP by ferrioxalate-assisted solar photo-Fenton process at mild $\mathrm{pH}$ with a low iron concentration. The effect of main experiment parameters, such as initial concentrations of $\mathrm{H}_{2} \mathrm{O}_{2}$ and $\mathrm{Fe}(\mathrm{II}), \mathrm{pH}$ and iron/oxalic acid molar ratios on total organic carbon (TOC) abatement has been assessed, and the accumulation of $\mathrm{H}_{2} \mathrm{O}_{2}$, $\mathrm{Fe}(\mathrm{II})$ and dissolved $\mathrm{O}_{2}$ has also been determined. In addition, a schematic reaction mechanism involving the iron cycle, radical reactions and PCP mineralization has been proposed. A possible pathway for the degradation of PCP is presented according to the identified intermediates.

\section{Experimental}

\subsection{Chemicals}

PCP was purchased from Sigma Aldrich (97\% purity) and used without further purification. Hydrogen peroxide, ferrous sulfate heptahydrate and oxalic acid dihydrate were obtained from Union Chemical, Merck and Sigma Aldrich, respectively. The solution $\mathrm{pH}$ was adjusted with diluted $\mathrm{NaOH}$ or $\mathrm{H}_{2} \mathrm{SO}_{4}$. Other chemicals used herein were of analytical grade. Laboratory-grade deionized water 
from a reverse osmosis system (resistivity $>18.2 \mathrm{M} \Omega \mathrm{cm}$ ) was used to prepare all aqueous solutions.

\subsection{Experimental procedures}

The experiments were carried out in an undivided glass cell filled with $1 \mathrm{~L}$ of PCP solution, under constant magnetic stirring and $\mathrm{pH}$ monitoring (see setup in Fig. S1). All the trials were performed with the initial PCP concentration fixed at $50 \mathrm{mg} / \mathrm{L}$, which is almost the solubility limit of PCP at circumneutral pH. In the dark, oxalic acid was mixed with the pollutant solution and then, the $\mathrm{Fe}(\mathrm{II})$ salt was added as catalyst source. The mixture was homogenized for 5 min before $\mathrm{pH}$ adjustment. Finally, as the cell was exposed to sunlight, a small $\mathrm{H}_{2} \mathrm{O}_{2}$ volume was added to initiate the photo-Fenton treatment. Samples were withdrawn at different time intervals, being immediately mixed with $\mathrm{NaOH}$ to quench the reaction and then analyzed after filtration on a $0.22 \mu \mathrm{m}$ syringe filter. The $\mathrm{pH}$ was controlled along the experiments to keep an almost constant value. The average UVA irradiance upon exposure to sunlight was measured on a UV radiometer (SENTRY ${ }^{\circledR}$, ST-513), placed next to the cell, which measured within the wavelength range from 290 to $370 \mathrm{~nm}$. All the trials were performed between 11 am and 2 pm on sunny days from May to June 2017 at Tainan (Taiwan). As can be observed in Fig. S2, during this period the average UVA irradiance was around $40 \mathrm{~W} / \mathrm{m}^{2}$. Note that, UVA irradiance showed approximately $7.6 \mathrm{~W} / \mathrm{m}^{2}$ difference at $11 \mathrm{AM}$ between May and June. Fortunately, it is believed that such difference has insignificant influence on the performance of ferrioxalate-assisted solar photo-Fenton process (Souza et al., 2014). 


\subsection{Analytical methods}

The mineralization of PCP solutions was assessed from the time course of TOC, measured on a TOC analyzer (Sievers 900, GE). The residual amount of $\mathrm{H}_{2} \mathrm{O}_{2}$ during the treatment was analyzed using the titanium sulfate method (Eisenberg, 1943). The Fe(II) concentration was measured using the 1,10-phenanthroline method (Tamura et al., 1974). Released $\mathrm{Cl}^{-}$ions were quantified by inductively coupled plasma optical emission spectrometry (Ultima 2000 ICP-OES spectrometer from Horiba Scientific). Dissolved oxygen (DO) was measured on an Oxi 3210 instrument from WTW. The carboxylic acids were determined at $\lambda=210 \mathrm{~nm}$ by ion-exclusion HPLC using a Waters 600 LC fitted with a Bio-Rad Aminex HPX 87H, $300 \mathrm{~mm} \times 7.8 \mathrm{~mm}$, column at $35{ }^{\circ} \mathrm{C}$. The elution was carried out by using $4 \mathrm{mM} \mathrm{H}_{2} \mathrm{SO}_{4}$ as mobile phase at 0.6 $\mathrm{mL} / \mathrm{min}$. The aromatic by-products were analyzed by gas chromatography coupled to mass spectrometry (GC-MS) using an Agilent Technologies system composed of a 6890N gas chromatograph and a 5975C mass spectrometer operating in EI mode at 70 $\mathrm{eV}$. Around $150 \mathrm{~mL}$ of aqueous sample was withdrawn from the cell to extract the organic components with $\mathrm{CH}_{2} \mathrm{Cl}_{2}$ in three times (25 mL each). The resulting organic solution was dried over anhydrous $\mathrm{Na}_{2} \mathrm{SO}_{4}$, filtered and concentrated to less than 1 mL under reduced pressure to be further analyzed. The mass spectra were identified with support from NIST05 MS library.

\section{Results and discussion}

\subsection{Comparative study of PCP mineralization}


containing $50 \mathrm{mg} / \mathrm{L}$ (i.e., $14 \mathrm{mg} / \mathrm{L}$ TOC) at $\mathrm{pH} 5.0$ by different processes was

conducted. As shown in Fig. 1, direct solar photolysis had no effect on TOC

abatement for $120 \mathrm{~min}$. This agrees with the low photodegradation rate constants at

PCP concentrations of $0.4-2.1 \mathrm{mg} / \mathrm{L}$, within the range of $4.9 \times 10^{-2}-7.1 \times 10^{-2} \mathrm{~h}^{-1}$, which

informs about the great persistence of this pollutant in the environment (Agbo et al.,

2011). The PCP mineralization by conventional Fenton process with $2 \mathrm{mM} \mathrm{H}_{2} \mathrm{O}_{2}$ was also very inefficient due to the low Fe(II) dosage (i.e., $5 \mathrm{mg} / \mathrm{L}$ ) and the expected

$\mathrm{Fe}(\mathrm{III})$ precipitation at $\mathrm{pH}$ 5.0. When the same trial was carried out in the presence of such conditions, in spite of the solubilization of Fe(III) upon chelation with oxalate, the regeneration of Fe(II) to promote Fenton's reaction was quite poor. A much better performance was shown by processes with sunlight irradiation. Solar photo-Fenton process with $5 \mathrm{mg} / \mathrm{L} \mathrm{Fe(II)} \mathrm{and} 2 \mathrm{mM} \mathrm{H}_{2} \mathrm{O}_{2}$ yielded 21\% TOC decay after $120 \mathrm{~min}$.

177 Such an upgrade as compared to trials in the dark can be mainly explained by the 178 photoreduction of $\mathrm{Fe}(\mathrm{III})$-hydroxy complexes to generate $\mathrm{Fe}(\mathrm{II})$ and ${ }^{\circ} \mathrm{OH}$ (Eq. (1)), 179 along with the photodecarboxylation of $\mathrm{Fe}(\mathrm{III})$ complexes of by-products formed 180 during the degradation of PCP (Eq. (2)). TOC abatement increased up to $50 \%$ in 181 ferrioxalate-assisted solar photolysis process with $1.2 \mathrm{mM} \mathrm{H}_{2} \mathrm{C}_{2} \mathrm{O}_{4}$. According to Eqs. 182 (3)-(8), $\mathrm{O}_{2}{ }^{--}$and ${ }^{\circ} \mathrm{OH}$ can be generated via several chain reactions in the presence of $\mathrm{O}_{2}$ and hence, these two radical species may play key roles for the degradation of the parent molecule and its by-products. However, the limited dissolved oxygen 
185

186

187

concentration in the solution significantly restricted the importance of Eqs. (5) and (6), which allows explaining the slower PCP removal from 30 min. The most effective process to degrade PCP was ferrioxalate-assisted solar photo-Fenton, yielding 97.5\% TOC removal at $120 \mathrm{~min}$, accompanied by the precipitation of iron hydroxide. Note that, although the addition of $1.2 \mathrm{mM} \mathrm{H}_{2} \mathrm{C}_{2} \mathrm{O}_{4}$ accounted for 28.8 mg/L TOC, almost total abatement organic carbon from PCP and oxalic acid was attained in the ferrioxalate-assisted solar photo-Fenton process. This positive result is attributed to the high yield of ${ }^{\circ} \mathrm{OH}$ formed in the presence of sufficient $\mathrm{H}_{2} \mathrm{O}_{2}$ and efficiently regenerated Fe(II) by Eqs. (3) and (4).

\subsection{Effect of $\mathrm{H}_{2} \mathrm{O}_{2}$ and $\mathrm{Fe}(\mathrm{II})$ dosage}

The amount of added $\mathrm{H}_{2} \mathrm{O}_{2}$ plays a relevant role in ferrioxalate-assisted solar photo-Fenton process, as it is the source of ${ }^{\circ} \mathrm{OH}$ upon catalyzed decomposition with Fe(II). Several trials were carried out with solutions of $50 \mathrm{mg} / \mathrm{L}$ PCP with $5 \mathrm{mg} / \mathrm{L}$ Fe(II) and $1.2 \mathrm{mM} \mathrm{H}_{2} \mathrm{C}_{2} \mathrm{O}_{4}$ at $\mathrm{pH}$ 5.0, employing different $\mathrm{H}_{2} \mathrm{O}_{2}$ concentrations. As shown in Fig. 2a, the decay of TOC after 120 min of irradiation increased from 50\% to $97 \%$ when the $\mathrm{H}_{2} \mathrm{O}_{2}$ content was increased from 0 to $1.5 \mathrm{mM}$. Further increase of $\mathrm{H}_{2} \mathrm{O}_{2}$ dosage up to $2.5 \mathrm{mM}$ resulted in a quicker mineralization during the first 60 min, whereupon close profiles were observed until reaching the same TOC removals at the end of the treatments. The significant acceleration using up to $1.5 \mathrm{mM} \mathrm{H}_{2} \mathrm{O}_{2}$ was then due to the faster production of 'OH from Fenton's reaction (Soares et al., 2015). However, an excess of $\mathrm{H}_{2} \mathrm{O}_{2}$ was detrimental because: (i) it acts as a radical scavenger, greatly reducing the amount of ${ }^{\circ} \mathrm{OH}$ according to Eqs. (9) and (10), and (ii) 

al., 2015).

$$
\bullet \mathrm{OH}+\mathrm{H}_{2} \mathrm{O}_{2} \rightarrow \mathrm{HO}_{2}^{\bullet}+\mathrm{H}_{2} \mathrm{O}
$$

$\mathrm{HO}_{2} \cdot{ }^{\bullet} \mathrm{OH} \rightarrow \mathrm{H}_{2} \mathrm{O}+\mathrm{O}_{2}$

$2 \mathrm{H}_{2} \mathrm{O}_{2} \rightarrow 2 \mathrm{H}_{2} \mathrm{O}+\mathrm{O}_{2}$

In order to elucidate the effect of Fe(II) dosage on the mineralization ability of

the ferrioxalate-assisted solar photo-Fenton treatment of solutions of $50 \mathrm{mg} / \mathrm{L} \mathrm{PCP \text {, }}$ $\mathrm{Fe}(\mathrm{II})$ catalysts amounts within the range of 2-10 $\mathrm{mg} / \mathrm{L}$ were added in the presence of $2.0 \mathrm{mM} \mathrm{H}_{2} \mathrm{O}_{2}$ and $1.2 \mathrm{mM} \mathrm{H}_{2} \mathrm{C}_{2} \mathrm{O}_{4}$ at $\mathrm{pH}$ 5.0. The results depicted in Fig. 2b illustrate a significant enhancement of TOC abatement upon increase of $\mathrm{Fe}(\mathrm{II})$ dosage within the early stage ( $20 \mathrm{~min})$. Hence, a higher catalyst concentration greatly accelerated the decomposition of $\mathrm{H}_{2} \mathrm{O}_{2}$, which resulted in a larger accumulation of ${ }^{\circ} \mathrm{OH}$ responsible for the mineralization. However, the final TOC removal at $120 \mathrm{~min}$ decreased from $97.5 \%$ to $91.4 \%$ when the dosage was increased from $5 \mathrm{mg} / \mathrm{L}$ to 10

$\mathrm{Fe}^{2+}+\cdot \mathrm{OH} \rightarrow \mathrm{Fe}^{3+}+\mathrm{OH}^{-}$

Furthermore, rapid accumulation of ${ }^{\circ} \mathrm{OH}$ during the initial stage is associated to a quicker decomposition of oxalate ligand and iron/oxalate complex (Eq. (13)). As the treatment proceeds, an increasing amount of $\mathrm{Fe}(\mathrm{III})$ cannot be complexed and maintained soluble and stable, which stimulates the formation of $[\mathrm{Fe}(\mathrm{OH})]^{2+}$ (Eq. (14)) and its further hydrolysis and precipitation as $\mathrm{Fe}(\mathrm{OH})_{3}$ (Eq. (15)) (Pliego et al., 2014). 
229

230

231

232

233

234

235

236

237

238

239

240

241

242

243

$\left[\mathrm{Fe}\left(\mathrm{C}_{2} \mathrm{O}_{4}\right)_{\mathrm{n}}\right]^{3-2 \mathrm{n}}+\cdot \mathrm{OH} \rightarrow \mathrm{Fe}^{3+}+$ Oxidized products

$[\mathrm{Fe}(\mathrm{OH})]^{2+}+2 \mathrm{H}_{2} \mathrm{O} \leftrightarrow \mathrm{Fe}(\mathrm{OH})_{3} \downarrow+2 \mathrm{H}^{+}$

In addition, a larger quantity of $\mathrm{Fe}(\mathrm{III})$ hydroxyde sludge may reduce the transparency of the solution, thus reducing the photocatalysis efficiency.

\subsection{Effect of $p H$ and iron/oxalic acid ratio}

Since PCP is quite insoluble at low $\mathrm{pH}$, supersaturated PCP solutions (i.e., 50 $\mathrm{mg} / \mathrm{L}$ ) were prepared to start the experiments at $\mathrm{pH}$ 5.0. After $15 \mathrm{~min}$ of ferrioxalate-assisted solar photo-Fenton treatment, the $\mathrm{pH}$ was adjusted to a given value to investigate its effect on TOC decay. As can be seen in Fig. 2c, similar trends reaching more than $95 \%$ TOC removal at 120 min were obtained at $\mathrm{pH} \leq 6.0$ in the

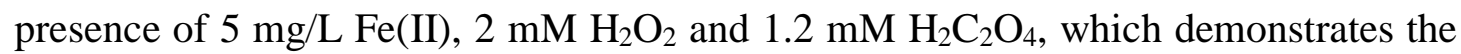
feasibility of working at mild $\mathrm{pH}$ thanks to the use of ferrioxalate complexes. In contrast, at $\mathrm{pH} \geq 7$, TOC remained almost constant, probably as a result of massive iron precipitation. Indeed, $\mathrm{pH}$ plays a crucial role regarding the speciation of iron, oxalic acid and ferrioxalate complexes (Panias et al., 1996). Different species including $\mathrm{H}_{2} \mathrm{C}_{2} \mathrm{O}_{4}, \mathrm{HC}_{2} \mathrm{O}_{4}{ }^{-}$and $\mathrm{C}_{2} \mathrm{O}_{4}{ }^{2-}$ may coexist in aqueous medium, since oxalic acid exhibits two ionization equilibria $\left(\mathrm{p} K_{1}=1.25\right.$ and $\left.\mathrm{p} K_{2}=4.27\right) . \mathrm{C}_{2} \mathrm{O}_{4}{ }^{2-}$, the predominant species at $\mathrm{pH}>4.27$, is considered as the main source to form different ferrioxalate complexes in the presence of iron, being the complex formed by $\mathrm{HC}_{2} \mathrm{O}_{4}^{-}$ negligible at $\mathrm{pH}>2.0$ (Souza et al., 2014). The performance of ferrioxalate-assisted solar photo-Fenton process highly depends on the photoactivity and stability of iron 
251

252

complexes, whose species distribution depends on both, solution $\mathrm{pH}$ and iron/oxalic acid ratio. Fig. S3 reveals the $\mathrm{Fe}(\mathrm{III})$ speciation diagrams as a function of $\mathrm{pH}$ in the presence of $5 \mathrm{mg} / \mathrm{L} \mathrm{Fe(II)} \mathrm{with} \mathrm{different} \mathrm{iron/oxalic} \mathrm{acid} \mathrm{molar} \mathrm{ratios,} \mathrm{as} \mathrm{determined}$ using MATLAB. The corresponding equilibrium reactions and constants are listed in Table S1. As can be seen in Fig S3 (e), which shows the speciation corresponding to the case in which the same Fe(II) and oxalic acid concentrations of trials of Fig. 2c are used, the predominant species are $\mathrm{Fe}\left(\mathrm{C}_{2} \mathrm{O}_{4}\right)_{3}{ }^{3-}$ and $\mathrm{Fe}\left(\mathrm{C}_{2} \mathrm{O}_{4}\right)_{2}{ }^{-}$at $3.0<\mathrm{pH}<7.0$. The former ferrioxalate complex is considered as the most stable and photoactive iron complex (Faust and Zepp, 1993), being efficiently photoreduced to Fe(II) that reacts with $\mathrm{H}_{2} \mathrm{O}_{2}$ to generate ${ }^{\circ} \mathrm{OH}$. This is highly consistent with the profiles presented in Fig. 2c, evidencing an outstanding performance and negligible difference of TOC decays when $\mathrm{pH}$ varied from 3.0 to 6.0 . Conversely, only $3.7 \%$ mineralization was achieved once the $\mathrm{pH}$ of the PCP solution was adjusted to 7.0, which can be accounted for by: (i) the preferential precipitation of $\mathrm{Fe}(\mathrm{III})$ over ferrioxalate formation (Fig. S3e), (ii) the gradual photodecarboxylation of ferrioxalate complexes, which accelerates the formation of $\mathrm{Fe}(\mathrm{OH})_{3(\mathrm{~s})}$, and (iii) the enhanced transformation of ${ }^{\circ} \mathrm{OH}$ into $\mathrm{O}_{2}{ }^{-}{ }^{-}$at high $\mathrm{pH}$.

Several experiments were performed at $\mathrm{pH} 5.0$ to evaluate the effect of the iron/oxalic acid ratio. As shown in Fig. 2d, almost complete TOC removal was obtained at molar ratios of 1:6, $1: 10$ and 1:13.5, whereas only $21.4 \%$ mineralization was achieved without the addition of oxalic acid. In the absence of oxalate anion, the predominant $\mathrm{Fe}(\mathrm{III})$ species at $\mathrm{pH} 5.0$ is $\left[\mathrm{Fe}(\mathrm{OH})_{2}\right]^{+}$(Fig. S3a), which is much less 
273 photoactive than $[\mathrm{Fe}(\mathrm{OH})]^{2+}$ that is typically formed in conventional Fenton process 274 at $\mathrm{pH} \sim 3.0$ (Eq. (1)). Using the 1:3 iron/oxalic acid ratio, $\mathrm{Fe}\left(\mathrm{C}_{2} \mathrm{O}_{4}\right)_{3}{ }^{3-}(56.0 \%)$ and $275 \mathrm{Fe}\left(\mathrm{C}_{2} \mathrm{O}_{4}\right)_{2}^{-}(43.1 \%)$ account for the largest proportion of $\mathrm{Fe}(\mathrm{III})$ species at $\mathrm{pH} 5.0$ 276 (Fig. S3b). The higher photoactivity of these complexes enhances the regeneration of $277 \mathrm{Fe}(\mathrm{II})$, yielding a greater mineralization as compared to the trial with 1:0 ratio (Fig. 278 2d). Increasing the iron/oxalic acid ratio to 1:6 (Fig. S3c), the molar fraction of the 279 very photoactive $\mathrm{Fe}\left(\mathrm{C}_{2} \mathrm{O}_{4}\right)_{3}{ }^{3-}$ complex increases to $89.9 \%$, with $\mathrm{Fe}\left(\mathrm{C}_{2} \mathrm{O}_{4}\right)_{2}{ }^{-}$ 280 decreasing to $10.1 \%$ at $\mathrm{pH}$ 5.0, which justifies the faster and almost complete TOC decay. The abatement was slightly decelerated at ratios of 1:10 and 1:13.5 (Fig. 2d),

despite the fact that the $\mathrm{Fe}\left(\mathrm{C}_{2} \mathrm{O}_{4}\right)_{3}{ }^{3-}$ species accounted for more than $95 \%$ of $\mathrm{Fe}(\mathrm{III})$, because of the significant increase of initial TOC in solution from oxalic acid that competed with PCP to react with ${ }^{\circ} \mathrm{OH}$.

It can then be concluded that the optimum performance of the ferrioxalate-assisted solar photo-Fenton process takes place at $\mathrm{pH} 5.0$, with an iron/oxalic acid molar ratio of 1:6.

\subsection{Evolution of $\mathrm{H}_{2} \mathrm{O}_{2}, \mathrm{Fe}(\mathrm{II})$ and dissolved $\mathrm{O}_{2}$}

The evolution of $\mathrm{H}_{2} \mathrm{O}_{2}$ and $\mathrm{Fe}(\mathrm{II})$ along the ferrioxalate-assisted solar photo-Fenton treatments collected in Fig. 2d is depicted in Fig. 3a and b, respectively. As shown in Fig. 3a, 40\% consumption of $\mathrm{H}_{2} \mathrm{O}_{2}$ was achieved after 120 min in the absence of oxalic acid, whereas it reached more than $93 \%$ in only $60 \mathrm{~min}$ at all iron/oxalic acid ratios, thus confirming the efficient $\mathrm{Fe}(\mathrm{II})$ regeneration upon photoreduction of the ferrioxalate complexes. More in detail, rising the molar ratio 
295

296

297

298

299

300

301

302

303

304

305

306

307

308

309

310

311

312

313

314

315

316

from 1:3 to 1:6 accelerated the decomposition of $\mathrm{H}_{2} \mathrm{O}_{2}$, but further increase of oxalic acid content slowed down the $\mathrm{H}_{2} \mathrm{O}_{2}$ disappearance. In fact, the $\mathrm{H}_{2} \mathrm{O}_{2}$ concentration measured at 2 and 5 min using a molar ratio of 1:13.5 was even higher than that at time zero, which can be attributed to the additional generation of $\mathrm{H}_{2} \mathrm{O}_{2}$ from the reaction sequence given by Eqs. (3)-(8). As can be observed, DO plays a major role in the formation of $\mathrm{H}_{2} \mathrm{O}_{2}$ and hence, its evolution with treatment time was evaluated in different cases. As depicted in Fig.4, the concentration of oxygen dissolved in the PCP solution decreased considerably in ferrioxalate-assisted solar photo-Fenton and solar photolysis processes, whereas it remained stable in conventional Fenton and solar photo-Fenton, which verifies the key role of DO in the aforementioned reactions to form $\mathrm{H}_{2} \mathrm{O}_{2}$. This means that this additional amount of $\mathrm{H}_{2} \mathrm{O}_{2}$ is able to react with $\mathrm{Fe}(\mathrm{II})$ to generate ${ }^{\circ} \mathrm{OH}$, which combined with other radical species $\left(\mathrm{C}_{2} \mathrm{O}_{4}{ }^{-}, \mathrm{CO}_{2}{ }^{-}\right.$and $\mathrm{O}_{2}{ }^{--}$) is responsible for the greater TOC abatement in ferrioxalate-assisted solar processes (Fig. 1). Note that the DO concentration in both ferrioxalate systems tended to increased again from 30 min, which can be explained by the quick chemical and photochemical decomposition of ferrioxalate complexes, especially in solar photo-Fenton process (Fig. 1).

On the other hand, Fig. 3b reveals the evolution of Fe(II) at different iron/oxalic acid ratios. The catalyst concentration decreased to less than $1 \mathrm{mg} / \mathrm{L}$ in only $2 \mathrm{~min}$ in the absence of oxalate because of the quick consumption by $\mathrm{H}_{2} \mathrm{O}_{2}$. The resulting $\mathrm{Fe}(\mathrm{III})$ ion was pre-eminently in a poorly photoactive form at $\mathrm{pH} 5.0\left(\left[\mathrm{Fe}(\mathrm{OH})_{2}\right]^{+}\right.$, see Fig. S3a), thus being difficult to regenerate $\mathrm{Fe}(\mathrm{II})$. The decrease in $\mathrm{Fe}(\mathrm{II})$ 
concentration was greatly decelerated upon increase of oxalic acid content, which confirms the very efficient photoreduction of ferrioxalate complexes. Nevertheless, owing to oxalic acid decomposition, the generated $\mathrm{Fe}(\mathrm{III})$ tended to precipitate at $\mathrm{pH}$ 5.0, eventually causing the decrease of Fe(II) concentration. Theoretically, all iron should be complexed at iron/oxalic acid molar ratios higher than 1:3 (Souza et al., 2014), but the continuous photodecarboxylation and decomposition of ferrioxalate complexes by ${ }^{\circ} \mathrm{OH}$ could cause the partial precipitation of iron. However, the use of a large amount of oxalic acid ensures the ion stabilization by formation of ferrioxalate complexes, especially at $\mathrm{pH}$ higher than 3.1. As can be seen in Fig. 3b, the concentration of $\mathrm{Fe}(\mathrm{II})$ kept the highest value (i.e., $5 \mathrm{mg} / \mathrm{L}$ ) for $20 \mathrm{~min}$ at an iron/oxalic acid molar ratio of 1:13.5, which is very positive to promote Fenton's reaction. Nonetheless, an excessively high amount of oxalic acid increases the operation costs, causes the competition with PCP to react with ${ }^{\circ} \mathrm{OH}$ and results in a higher initial TOC and thus, the iron/oxalic acid ratio should be carefully considered for real applications.

\subsection{Possible reaction mechanism of ferrioxalate-assisted solar photo-Fenton process}

Based on all previous results, a reaction mechanism for the ferrioxalate-assisted solar photo-Fenton treatment of PCP is proposed in Fig. $5 . \mathrm{Fe}^{3+}$ can be complexed by oxalate, and the efficient photoreduction of the resulting Fe(III) complexes eventually yields $\mathrm{Fe}(\mathrm{II})$, either as free $\mathrm{Fe}^{2+}$ or complexed with oxalate, which readily reacts with $\mathrm{H}_{2} \mathrm{O}_{2}$ to generate ${ }^{\circ} \mathrm{OH}$ and $\mathrm{Fe}(\mathrm{III})$ in a closed loop. However, owing to the progressive decomposition of ferrioxalate complexes, the excess of Fe(III) tends to precipitate as 
$\mathrm{Fe}(\mathrm{OH})_{3(\mathrm{~s})}$ at $\mathrm{pH}$ higher than 3.1. In the presence of $\mathrm{O}_{2}$, additional amounts of $\mathrm{H}_{2} \mathrm{O}_{2}$ and concomitant radical species $\left(\mathrm{C}_{2} \mathrm{O}_{4}{ }^{-}, \mathrm{CO}_{2}{ }^{-}, \mathrm{HO}_{2}{ }^{\cdot}\right.$ and $\left.\mathrm{O}_{2}{ }^{-}\right)$can be generated according to a series of radical reactions, although their oxidization ability is much weaker than that of ${ }^{\circ} \mathrm{OH}$. Therefore, the degradation and mineralization of PCP can be pre-eminently explained in terms of reactions with ${ }^{\circ} \mathrm{OH}$, as in the case if classical Fenton’s reaction.

\subsection{Identification of degradation by-products}

In surface water and sediments, the toxicity of PCP has been evidenced at concentrations greater than $3 \mathrm{mg} / \mathrm{L}$ (Stepanova et al., 2000). Some intermediates generated during the degradation of this target pollutant, like 3,4,5-trichlorophenol, are known to be even more toxic, as the toxicity is related to the number of chlorine atoms and their position (Lin et al., 2018). Therefore, the release of $\mathrm{Cl}^{-}$and the generation of PCP reaction by-products have been investigated. Fig. 6a reveals the evolution of $\mathrm{Cl}^{-}$ion with irradiation time during the ferrioxalate-assisted solar photo-Fenton treatment of $50 \mathrm{mg} / \mathrm{L}$ PCP with $5 \mathrm{mg} / \mathrm{L} \mathrm{Fe(II),} 2 \mathrm{mM} \mathrm{H}_{2} \mathrm{O}_{2}$ and $1.2 \mathrm{mM}$ $\mathrm{H}_{2} \mathrm{C}_{2} \mathrm{O}_{4}$. As can be seen, the degradation of PCP was accompanied by a continuous release of $\mathrm{Cl}^{-}$, whose concentration increased with over time up to attain $33.5 \mathrm{mg} / \mathrm{L}$ (i.e., 100\% release) at $90 \mathrm{~min}$, thus informing about the excellent dechlorination performance and the total removal of organochlorine intermediates generated during the degradation of PCP in this process. Fig. $6 \mathrm{~b}$ reveals the evolution of five carboxylic acids like oxalacetic, malonic, succinic, formic and acetic resulting from the cleavage of the aromatic rings. The maximum concentration of succinic acid was $5.9 \mathrm{mg} / \mathrm{L}$ at 
361

362

$30 \mathrm{~min}$, whereas lower contents of the other acids were accumulated, reaching maximum values of 2.1, 1.4, 0.9 and $0.7 \mathrm{mg} / \mathrm{L}$ for malonic, oxalacetic, formic and acetic acids at 20, 30, 45 and $45 \mathrm{~min}$, respectively. The accumulation of these carboxylic acids entails the occurrence of competing Fe(III)-carboxylate complexes, which efficiently enhanced the Fe(II) regeneration via Eq. (2). Moreover, all the acids disappeared in 90-120 min, confirming the almost total mineralization achieved by ferrioxalate-assisted solar photo-Fenton process.

The main transformation products (TPs) identified by GC-MS analysis included four monobenzenic and four polycyclic molecules. As summarized in Table S2, these corresponded to tetrachlorophenol (TeCP), trichlorophenol (TriCP), trichlorohydroquinone (TrCHQ), tetrachlorohydroquinone (TeCHQ), hexachlorodibenzofuran (HCDF), pentachlorodibenzo-p-dioxin (PCDD), hexachlorodibenzo-p-dioxin (HCDD) and octachlorodibenzo-p-dioxin (OCDD). The cleavage of $\mathrm{C}-\mathrm{Cl}$ bonds yielded lower chlorinated structures like TeCP and TriCP (Liu et al., 2004). The subsequent attack of ${ }^{\circ} \mathrm{OH}$ onto their aromatic rings resulted in two hydroxylated TPs (TeCHQ and TrCHQ). Alternatively, the direct attack of ${ }^{\circ} \mathrm{OH}$ on C-Cl bonds of PCP can give rise to TeCHQ, which may be further dechlorinated. On the other hand, several dimeric structures were identified. Since PCP mainly exists as anionic form $\left(\mathrm{PCP}^{-}\right)$at $\mathrm{pH}>4.7$, hydroxylation of $\mathrm{PCP}^{-}$leads to the generation of pentachlorophenoxy radical $\left(\mathrm{PCP}^{\bullet}\right)$. Then, the coupling reaction between two PCP species or $\mathrm{PCP}^{\bullet}$ and $\mathrm{PCP}^{-}$may yield OCDD and $\mathrm{HCDF}$, respectively, with chloride release (Fukushima and Tatsumi, 2001). Further dechlorination of OCDD caused the 
formation of lower chlorinated derivatives like HCDD and PCDD. The degradation routes of PCP, which are depicted in Fig. 7, on the basis of the identified by-products, involve three paths: dechlorination, hydroxylation and dimerization.

\section{Conclusions}

Promising results were obtained for the mineralization of PCP at near-neutral pH using a low iron concentration by the ferrioxalate-assisted solar photo-Fenton process. More than 95\% TOC abatement were achieved in 120 min. The optimized operation parameters were: $5 \mathrm{mg} / \mathrm{L} \mathrm{Fe}(\mathrm{II}), 1.5 \mathrm{mM} \mathrm{H} \mathrm{H}_{2}$, pH 5.0 and iron/oxalic acid molar ratio of 1:6. The presence of oxalic acid greatly enhances the performance of solar photo-Fenton process due to various reasons: (i) the ferrioxalate complex ensures the iron solubility at mild $\mathrm{pH}$; (ii) the $\mathrm{Fe}(\mathrm{III})$ complexes with oxalate are highly photoactive, thus allowing the continuous Fe(II) regeneration; and (iii) additional amounts of $\mathrm{H}_{2} \mathrm{O}_{2}$ and radical species are generated with the involvement of $\mathrm{O}_{2}$. It was shown that $\mathrm{pH}$ and iron/oxalic acid molar ratio play crucial roles on the $\mathrm{Fe}(\mathrm{III})$ speciation in aqueous medium, greatly influencing the performance of the degradation process. At $\mathrm{pH}$ 3.0-7.0 and iron/oxalic acid ratio higher than 1:3, all the iron is complexed with oxalate, whereas the excess of oxalate ion remains in solution and ensures the continuous formation of ferrioxalate complexes that impedes the iron precipitation. The mineralization of PCP involves dechlorination, hydroxylation and 
402

403

404

405

406

407

408

409

410

411

412

decarboxylation steps, as well as the formation of some dimers that can be gradually degraded by ${ }^{\circ} \mathrm{OH}$ and other radicals.

\section{Acknowledgements}

This work was supported by Natural Science Foundation of Hubei Province, China (Grant 2012FFA089) and the National Science Council of the Republic of China (No. NSC 102-2622-E-006-004-CC2). The authors also thank financial support from project CTQ2016-78616-R (AEI/FEDER, EU) and PhD scholarship awarded to Z.H. Ye (State Scholarship Fund, CSC, China).

\section{References}

Agbo. S.O., Küster, E., Georgi, A., Akkanen, J., Leppänen, M.T., Kukkonen, J.V.K., 2011. Photostability and toxicity of pentachlorophenol and phenanthrene. J. Hazard. Mater. 189, 235-240.

Amendola, L., Cortese, M., Vinatoru, D., Sposato, S., Insogna, S., 2017. Innovative analytical method for the determination of underivatized tributyltin and pentachlorophenol in seawater by gas chromatography-triple quadrupole mass spectrometry. Anal. Chim. Acta 975, 70-77.

Brillas, E., Sirés, I., Oturan, M.A., 2009. Electro-Fenton process and related electrochemical technologies based on Fenton's reaction chemistry. Chem. Rev. 109, 6570-6631.

Clarizia, L., Russo, D., Somma, I.D., Marotta, R., Andreozzi, R., 2017. Homogeneous photo-Fenton processes at near neutral pH: A review. Appl. Catal. B: Environ. 
424

Cui, Y., Liang, L., Zhong, Q., He, Q., Shan, X., Chen, K., Huang, F., 2017. The association of cancer risks with pentachlorophenol exposure: Focusing on community population in the areas along certain section of Yangtze River in China, Environ. Pollut. 224, 729-738.

Eisenberg, G.M., 1943. Colorimetric determination of hydrogen peroxide. Ind. Eng. Chem. Anal. Ed. 15, 327-328.

Expósito, A.J., Monteagudo, J.M., Durán, A., Martín, I.S., González, L., 2018. Study of the intensification of solar photo-Fenton degradation of carbamazepine with ferrioxalate complexes and ultrasound. J. Hazard. Mater. 342, 597-605.

Faust, B.C., Zepp, R.G., 1993. Photochemistry of aqueous iron(III)-polycarboxylate complexes: roles in the chemistry of atmospheric and surface waters. Environ. Sci. Technol. 27, 2517-2522.

Fukushima, M., Tatsumi, K., 2001. Degradation pathways of pentachlorophenol by photo-Fenton systems in the presence of iron(III), humic acid, and hydrogen peroxide. Environ. Sci. Technol. 35, 1771-1778.

Guemiza, K., Coudert, L., Metahni, S., Mercier, G., Besner, S., Blais, J.F., 2017. Treatment technologies used for the removal of As, Cr, Cu, PCP and/or PCDD/F from contaminated soil: A review. J. Hazard. Mater. 333, 194-214.

He, Y., Zeng, F., Lian, Z., Xu, J., Brookes, P.C., 2015. Natural soil mineral nanoparticles are novel sorbents for pentachlorophenol and phenanthrene removal. Environ. Pollut. 205, 43-51. 
Hechmi, N., Bosso, L., El-Bassi, L., Scelza, R., Testa, A., Jedidi, N., Rao, M.A., 2016. Depletion of pentachlorophenol in soil microcosms with Byssochlamys nivea and Scopulariopsis brumptii as detoxification agents. Chemosphere 165, 547-554.

Khan, M.D., Khan, N., Nizami, A.S., Rehan, M., Sabir, S., Khan, M.Z., 2017. Effect of co-substrates on biogas production and anaerobic decomposition of pentachlorophenol. Bioresour. Technol. 238, 492-501.

Khuzwayo, Z., Chirwa, E.M.N., 2017. The impact of alkali metal halide electron donor complexes in the photocatalytic degradation of pentachlorophenol. J. Hazard. Mater. 321, 424-431.

Klamerth, N., Malato, S., Agüera, A., Fernández-Alba, A., Mailhot, G., 2012. Treatment of municipal wastewater treatment plant effluents with modified photo-Fenton as a tertiary treatment for the degradation of micro pollutants and disinfection. Environ. Sci. Technol. 46, 2885-2892.

Kwan, C.Y., Chu, W., 2007. The role of organic ligands in ferrous-induced photochemical degradation of 2,4-dichlorophenoxyacetic acid. Chemosphere 67, $1601-1611$.

Lin, J., Meng, J., He, Y., Xu, J., Chen, Z., Brookes, P.C., 2018. The effects of different types of crop straw on the transformation of pentachlorophenol in flooded paddy soil. Environ. Pollut. 233, 745-754.

Liu, X., Quan, X., Bo, L., Chen, S., Zhao, Y., 2004. Simultaneous pentachlorophenol decomposition and granular activated carbon regeneration assisted by 
microwave irradiation. Carbon 42, 415-422.

Luca, A.D., Dantas, R.F., Esplugas, S., 2014. Assessment of iron chelates efficiency for photo-Fenton at neutral pH. Water Res. 61, 232-242.

Manenti, D.R., Soares, P.A., Módenes, A.N., Espinoza-Quiñones, F.R., Boaventura, R.A.R., Bergamasco, R., Vilar, V.J.P., 2015. Insights into solar photo-Fenton process using iron(III)-organic ligand complexes applied to real textile wastewater treatment. Chem. Eng. J. 266, 203-212.

Martínez-Huitle, C.A., Rodrigo, M.A., Sirés, I., Scialdone, O., 2015. Single and coupled electrochemical processes and reactors for the abatement of organic water pollutants: A critical review. Chem. Rev. 115, 13362-13407.

Monteagudo, J.M., Durán, A., Martín, I.S., Aguirre, M., 2010. Catalytic degradation of Orange II in a ferrioxalate-assisted photo-Fenton process using a combined UV-A/C-solar pilot-plant system. Appl. Catal. B: Environ. 95, 120-129.

Monteagudo, J.M., Durán, A., Aguirre, M., Martín, I.S., 2010. Photodegradation of Reactive Blue 4 solutions under ferrioxalate-assisted UV/solar photo-Fenton system with continuous addition of $\mathrm{H}_{2} \mathrm{O}_{2}$ and air injection. Chem. Eng. J. 162, 702-709.

Monteagudo, J.M., Durán, A., Aguirre, M., Martín, I.S., 2011. Optimization of the mineralization of a mixture of phenolic pollutants under a ferrioxalate-induced solar photo-Fenton process. J. Hazard. Mater. 185, 131-139.

Niu, J., Bao, Y., Li, Y., Chai. Z., 2013. Electrochemical mineralization of pentachlorophenol (PCP) by $\mathrm{Ti} / \mathrm{SnO}_{2}-\mathrm{Sb}$ electrodes. Chemosphere 92, 
490

491

492

493

494

495

496

497

498

499

500

501

502

503

504

505

506

507

508

509

510

Panias, D., Taxiarchou, M., Douni, I., Paspaliaris, I., Kontopoulos, A., 1996. Thermodynamic analysis of the reactions of iron oxides: dissolution in oxalic acid. Can. Metall. Q. 35, 363-373.

Pignatello, J., Oliveros, E., MacKay, A., 2006. Advanced oxidation process for organic contaminant destruction based on the Fenton reaction and related chemistry. Crit. Rev. Environ. Sci. Technol. 36, 1-84.

Pliego, G., Zazo, J.A., Casas, J.A., Rodriguez, J.J., 2014. Fate of iron oxalates in aqueous solution: The role of temperature, iron species and dissolved oxygen. J. Environ. Chem. Eng. 2, 2336-2241.

Pouran, S.R., Aziz, A.R.A., Daud, W.M.A.W., 2015. Review on the main advances in photo-Fenton oxidation system for recalcitrant wastewaters. J. Ind. Eng. Chem. 21, 53-69.

Rahmani A.R., Jorfi S., Asgari G., Zamani F., Almasi H, Masoumi Z., 2018. A comparative study on the removal of pentachlorophenol using copper-impregnated pumice and zeolite. J. Environ. Chem. Eng. 6, 3342-3348.

Shih, Y.H., Chen, M.Y., Su, Y.F., Tso, C.P., 2016. Concurrent oxidation and reduction of pentachlorophenol by bimetallic zerovalent $\mathrm{Pd} / \mathrm{Fe}$ nanoparticles in an oxic water. J. Hazard. Mater. 301, 416-423.

Soares, P.A., Batalha, M., Souza, S.M.A.G.U., Boaventura, R.A.R., Vilar, V.J.P., 2015. Enhancement of a solar photo-Fenton reaction with ferric-organic ligands for the treatment of acrylic-textile dyeing. J. Environ. Manage. 152, 120-131. 
Souza, B.M., Dezotti, M.W.C., Boaventura, R.A.R., Vilar, V.J.P., 2014. Intensification of a solar photo-Fenton reaction at near neutral $\mathrm{pH}$ with ferrioxalate complexes: A case study on diclofenac removal from aqueous solutions. Chem. Eng. J. 256, 448-457.

Stepanova, L.I., Lindström-Seppä, P., Hänninen, O.O.P., Kotelevtsev, S.V., Glaser, V.M., Novikov, C.N., Beim, A.M., 2000. Lake Baikal: biomonitoring of pulp and paper mill waste water. Aquat. Ecosyst. Health Manage. 3, 259-269.

Tamura, H., Goto, K., Yotsuyanagi, T., Nagayama, M., 1974. Spectrophotometric determination of iron(III) with 1,10-phenanthroline in the presence of large amounts of iron(III). Talanta 21, 314-318.

Tsoufis, T., Katsaros, F., Kooi, B.J., Bletsa, E., Papageorgiou, S., Deligiannakis, Y., Panagiotopoulos, I., 2017. Halloysite nanotube-magnetic iron oxide nanoparticle hybrids for the rapid catalytic decomposition of pentachlorophenol. Chem. Eng. J. 313, 466-474.

Vedrenne, M., Vasquez-Medrano, R., Prato-Garcia, D., Frontana-Uribe, B.A., Hernandez-Esparza, M., Andrés, J.M.D., 2012. A ferrous oxalate mediated photo-Fenton system: toward an increased biodegradability of indigo dyed wastewaters. J. Hazard. Mater. 243, 292-301.

Ye, Z., Zhang, H., Yang, L., Wu, L., Qian, Y., Geng, J., Chen, M., 2016. Effect of a solar Fered-Fenton system using a recirculation reactor on biologically treated landfill leachate. J. Hazard. Mater. 319, 51-60.

Zhou, L., Pan, S., Chen, X., Zhao, Y., Zou, B., Jin, M., 2014. Kinetics and 

functionalized $\mathrm{Fe}_{3} \mathrm{O}_{4} @ \mathrm{SiO}_{2}-\mathrm{MWCNTs}$ core-shell magnetic microspheres. Chem. Eng. J. 257, 10-19. 